\title{
Effect of Dehydrated Digested Effluent of Manure on Yield and Quality of Annual Forages and Soil Chemical Properties in Southern Kyushu, Japan
}

\author{
Sachiko Idota, Yasuyuki Ishii \\ Faculty of Agriculture, University of Miyazaki, Miyazaki, Japan \\ Email: sidota@cc.miyazaki-u.ac.jp, yishii@cc.miyazaki-u.ac.jp
}

Received 20 June 2014; revised 23 July 2014; accepted 5 August 2014

Copyright (C) 2014 by authors and Scientific Research Publishing Inc.

This work is licensed under the Creative Commons Attribution International License (CC BY). http://creativecommons.org/licenses/by/4.0/

(c) (i) Open Access

\begin{abstract}
Digested effluent of manure (DEM) produced by biogas-plants contains many macro- and micronutrients. In an experiment conducted in southern Kyushu (Japan), forage crops cultivated after receiving DEM and chemical fertilizers exhibited similar dry matter yields. From a logistical standpoint, however, DEM in liquid form is difficult to handle and apply due to the low concentration of nutrients. To overcome this shortcoming, we prepared dehydrated DEM (DDEM) by adding DEM to cattle manure without disturbing the manure fermentation process. The objective of this research was to evaluate the effect of DDEM on dry matter yield and nitrogen recovery rate in annual dualcropping systems (summer crop of maize or sorghum and winter crop of Italian ryegrass) that are typical of the region and to compare these results to commercial cattle manure alone, in combination with chemical fertilizer (CM or CM + CF), or no fertilizer application (NF). In both cropping systems, the DDEM treatment produced similar dry matter yields (2.6 to $3.02 \mathrm{~kg} \cdot \mathrm{m}^{-2}$ ) and apparent nitrogen recovery rates $(43 \%$ to $53 \%)$ as the $C M+C F$ and $C M$ treatments. This suggests that DDEM can potentially replace chemical fertilizers and commercial cattle manure in the region.
\end{abstract}

\section{Keywords}

Digested Effluent of Manure, Annual Forage, Nitrogen Recovery, Yield

\section{Introduction}

Expansion of intensive livestock operations in southern Kyushu, Japan has increased concerns about nutrient 
overloading of croplands. Nitrogen derived from animal excreta has become a problem in the region [1]-[3]. In the context of increasing pressure from local communities to reduce the environmental impacts of livestock operations, composting is receiving increased attention as an environmentally friendly manure management practice [4] [5]. In addition, increasing fossil fuel prices in recent years has led to an increase in chemical fertilizer costs [6]. Anaerobic digestion in biogas plants is an alternative way to handle animal manure and to reduce greenhouse gas emissions [7]. The digested effluent of manure (DEM) produced by biogas plants constitutes a liquid organic fertilizer and contains many macro- and micro-nutrients and minerals. In Japan, DEM was firstly applied to temperate perennial species such as orchard grass in Hokkaido regions [8], and the use of DEM as fertilizer may reduce operating costs of biogas plants [9]. In Miyazaki at the border of temperate and subtropical regions, applications of DEM to representative annual summer forage crops such as maize or sorghum combined with winter crop of Italian ryegrass [10] and perennial tropical napiergrass [11] resulted in similar dry matter crop production to the application of fertilizer application. However, as a liquid fertilizer, DEM is difficult to manage due to its low nutrient concentration, and ammonium nitrogen derived from liquid DEM was lost evidently due to the emission to the atmosphere [8]. To overcome these demerits, we prepared dehydrated DEM (DDEM) by adding DEM to cattle manure without disturbing the manure fermentation process. The objectives of the current study were to determine the efficiency of DDEM application for increasing dry matter yield and nitrogen recovery rate in the annual double cropping systems typical of the region, and to compare these results with those yielded using commercial cattle manure with the same nitrogen rate amended and not amended with chemical fertilizer.

\section{Materials and Methods}

\subsection{Preparation of Digested Effluent of Manure (DEM) and Dehydrated DEM}

DEM was produced from swine feces in a biogas plant located within the University of Miyazaki. Total nitrogen $(\mathrm{N})$ and ammonium $\mathrm{N}$ contents of the DEM were $0.52 \%$ and $0.41 \%$, respectively. The N:P:K ratio of the DEM was 1.0:0.18:0.52, indicating that, among major nutrients, $\mathrm{N}$ content was highest. On average, share of total $\mathrm{N}$ in the form of ammonium $\mathrm{N}$ was $78 \%$, indicating that $\mathrm{N}$ was primarily present in an inorganic form.

Cattle dung, rice bran and thermophile bacteria (Thermobifidafusca, Planifilumyunnanense and Geobacillusthermodenitrificans) were mixed with manure $\left(50 \mathrm{~m}^{3}\right)$ and amended with DEM $(1060 \mathrm{~L})$ in a box $\left(60 \mathrm{~m}^{3}\right)$ and maintained in a pile in the compost depot and mixed every 2 to 5 days for 2 months. The fermentation process was completed in 2 months to produce DDEM.

\subsection{Field Trials}

A field trial was carried out in Miyazaki, Japan $\left(31^{\circ} 82^{\prime} \mathrm{N}, 131^{\circ} 40^{\prime} \mathrm{E}\right)$ in 2009. Soils were classified into medium and coarse-textured gray lowland soils. As for soil chemical properties, $\mathrm{pH}$ ranged between 6.2 and 6.6 and mean total $\mathrm{N}$ content, inorganic $\mathrm{N}$ content, and electric conductivity (EC) of the surface soil (0 to $15 \mathrm{~cm}$ depth) were $2.2 \mathrm{mg} \cdot \mathrm{g}^{-1}, 0.02 \mathrm{mg} \cdot \mathrm{g}^{-1}$, and $0.05 \mathrm{dS} \cdot \mathrm{m}^{-1}$, respectively. The cropping systems consisted of 2-crop rotation that included summer crops (maize or sorghum) and winter crop (Italian ryegrass). Field experiments were carried out with three replicates in a randomized block design with a plot size of $9 \mathrm{~m}^{2}(3 \mathrm{~m} \times 3 \mathrm{~m})$. Four types of fertilizer treatments were applied: conventional fertilizer (CM + CF, commercial cattle manure plus chemical fertilizer), commercial cattle manure (CM), dehydrated digested effluent of manure (DDEM), and no fertilizer $(\mathrm{NF})$. Nitrogen $(\mathrm{N})$ was applied at two levels in all fertilization treatments except for NF: 49.1 and $24.6 \mathrm{~g} \cdot \mathrm{N} \cdot \mathrm{m}^{-2}$ for summer and winter crops, respectively. These rates correspond to standard fertilization rates for forage crops in Miyazaki Prefecture. DDEM, CM and CF were basally applied once at the sowing. All plant samples were dried at $70^{\circ} \mathrm{C}$ for 72 hours in a hot air oven to determine dry matter content. Soil samples were taken at a depth of $0-15 \mathrm{~cm}$, air-dried, and then passed through a 2-mm screen.

\subsection{Chemical Analysis}

The elemental content of manure was measured using an ICP mass spectrometer (ICPS-8100, SHIMAZU, Kyoto). Soil $\mathrm{pH}$ and EC were determined using a glass electrode and platinum-titanium electrode, respectively [12]. Soil samples (5 g) were dissolved in $50 \mathrm{~mL}$ KCL (10\%) and extracted while shaking for $60 \mathrm{~min}$. The suspensions were filtered and analyzed for ammonium and nitrate $\mathrm{N}$ content using an auto-analyzer (SWAAT, BLTEC, 
Tokyo). Total soil and plant nitrogen (TN) were determined using an NC corder (Model NC-220F, Sumitomo Chemical Center Co. Ltd., Tokyo). The apparent $\mathrm{N}$ recovery rate was calculated as follows:

$$
\mathrm{N} \text { recovery rate }(\%)=(\text { Plant } \mathrm{N} \text { output }) /(\text { Fertilizer } \mathrm{N} \text { input }) \times 100 \text {. }
$$

\subsection{Available Nitrogen Content of Manure}

Aerobic incubation was performed according to the standard procedure [12]. In a $100 \mathrm{~mL}$ glass sample bottle, a mixture of soil ( $10 \mathrm{~g})$ and each manure (DDEM and CM) $(3.75 \mathrm{~g})$ was added to $4 \mathrm{~mL}$ distilled water. The samples were incubated $\left(30^{\circ} \mathrm{C}\right)$ for $0,3,7,14$ and 28 days. After incubation, samples were dissolved in $100 \mathrm{~mL}$ KCL (10\%) and extracted while shaking for $60 \mathrm{~min}$. The suspensions were filtered and analyzed for ammonium and nitrate $\mathrm{N}$ content using an auto-analyzer (SWAAT, BLTEC, Tokyo).

\subsection{Statistical Analysis}

Analysis of variance was performed using Excel Statistics (OMS Co. Ltd., Saitama). Differences in mean values were assessed at the $5 \%$ probability level using the Bonferroni multiple comparison procedure.

\section{Results and Discussion}

\subsection{Mineral Content of Manure}

The moisture contents of fresh DDEM and CM were 143 and $438 \mathrm{mg} \cdot \mathrm{g}^{-1}$, respectively (Table 1), indicating that DDEM has a lower specific gravity than CM, and is easier to handle than liquid DEM. Table 1 shows that DDEM had higher total $\mathrm{N}$ and ammonium $\mathrm{N}$ content than $\mathrm{CM}$, and that the share of total $\mathrm{N}$ represented by inorganic N (ammonium plus nitrate) were 8.4\% and 19.1\% in DDEM and CM, respectively. DDEM and CM had similar contents of other elements except for potassium and calcium, which were higher in DDEM than CM. It was evident that DDEM had higher mineral contents of total nitrogen, phosphorus, potassium and calcium at DM basis than liquid DEM processed from dairy cattle slurry [13].

\subsection{Plant Growth}

Figure 1 summarizes dry matter yields at harvest of the two cropping systems. Dry matter yields of maize for

Table 1. Mineral and moisture content of dehydrated digested effluent of manure (DDEM) and commercial manure (CM).

\begin{tabular}{ccc}
\hline \multirow{2}{*}{ Mineral content $\left(\mathrm{mg} \cdot \mathrm{g} \cdot \mathrm{DM}^{-1}\right)^{\mathrm{a}}$} & Manure & $\mathrm{CM}$ \\
\cline { 2 - 3 } Total nitrogen & DDEM & 17.3 \\
Ammonium nitrogen & 23.8 & 0.1 \\
Nitrate nitrogen & 0.4 & 3.2 \\
Total carbon & 1.6 & 290.0 \\
Sodium & 459.4 & 6.0 \\
Magnesium & 5.8 & 8.2 \\
Aluminum & 6.5 & 6.2 \\
Phosphorus & 0.5 & 10.7 \\
Potassium & 11.8 & 32.2 \\
Calcium & 37.2 & 14.8 \\
Manganese & 24.6 & 0.4 \\
Iron & 0.2 & 2.7 \\
Zinc & 1.3 & 0.4 \\
Water (mg.g·FM $\left.{ }^{-1}\right)^{\mathrm{a}}$ & 0.2 & 438 \\
\hline
\end{tabular}

a. Dry matter (DM), Fresh matter (FM). 
the CM + CF, DDEM and CM treatments were 2053, 2184 and $1954 \mathrm{~g} \cdot \mathrm{m}^{-2}$, respectively. No significant differences in dry matter yield were observed between treatments for either summer crop in either cropping system. However, with regard to the winter crop, dry matter yield of Italian ryegrass was lowest for the NF treatment in both cropping systems, while yields for the DDEM treatment did not differ significantly from that for CM + CF or CM treatment in either cropping system. Effect of nutritive source of DDEM on plant growth in maize-Italian ryegrass croppings was almost similar with liquid DEM, compared with CM treatment [10]. Herrmann et al. (2013) examined that biogas residue from energy-cropping systems application resulted in similar maize yielding performance to pig and cattle slurry in Germany [14].

\subsection{Soil Chemical Properties}

Figure 2 summarizes the soil chemical properties of the two cropping systems under different fertilizer treat-

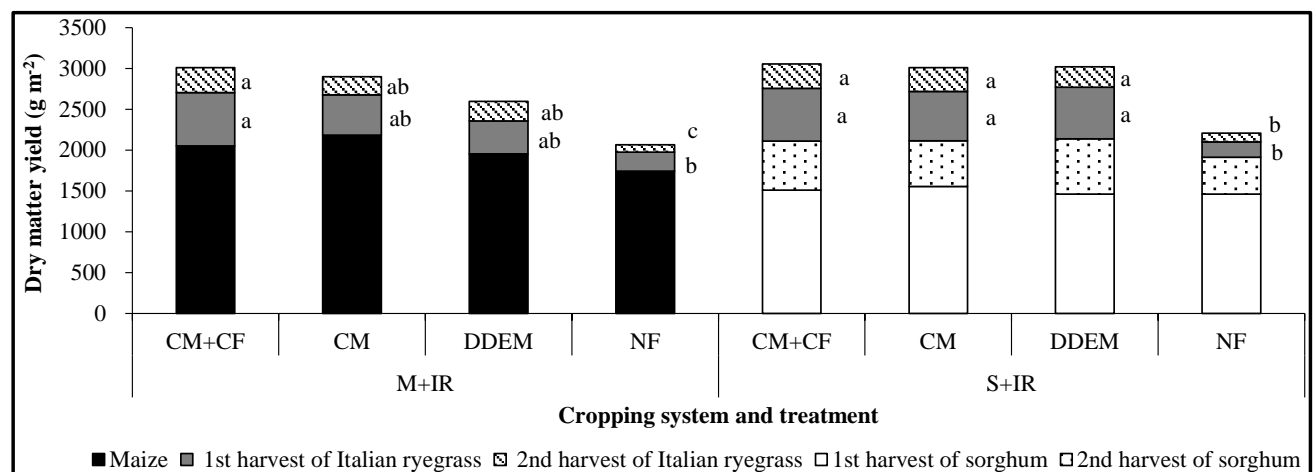

Figure 1. Dry matter yield in the two summer-winter cropping systems under different fertilizer treatments. Bar segments followed by different letters are different within the same crop at the 5\% level (Bonferroni test). For more information on the cropping systems and treatments, refer to the footnote in Table 2.

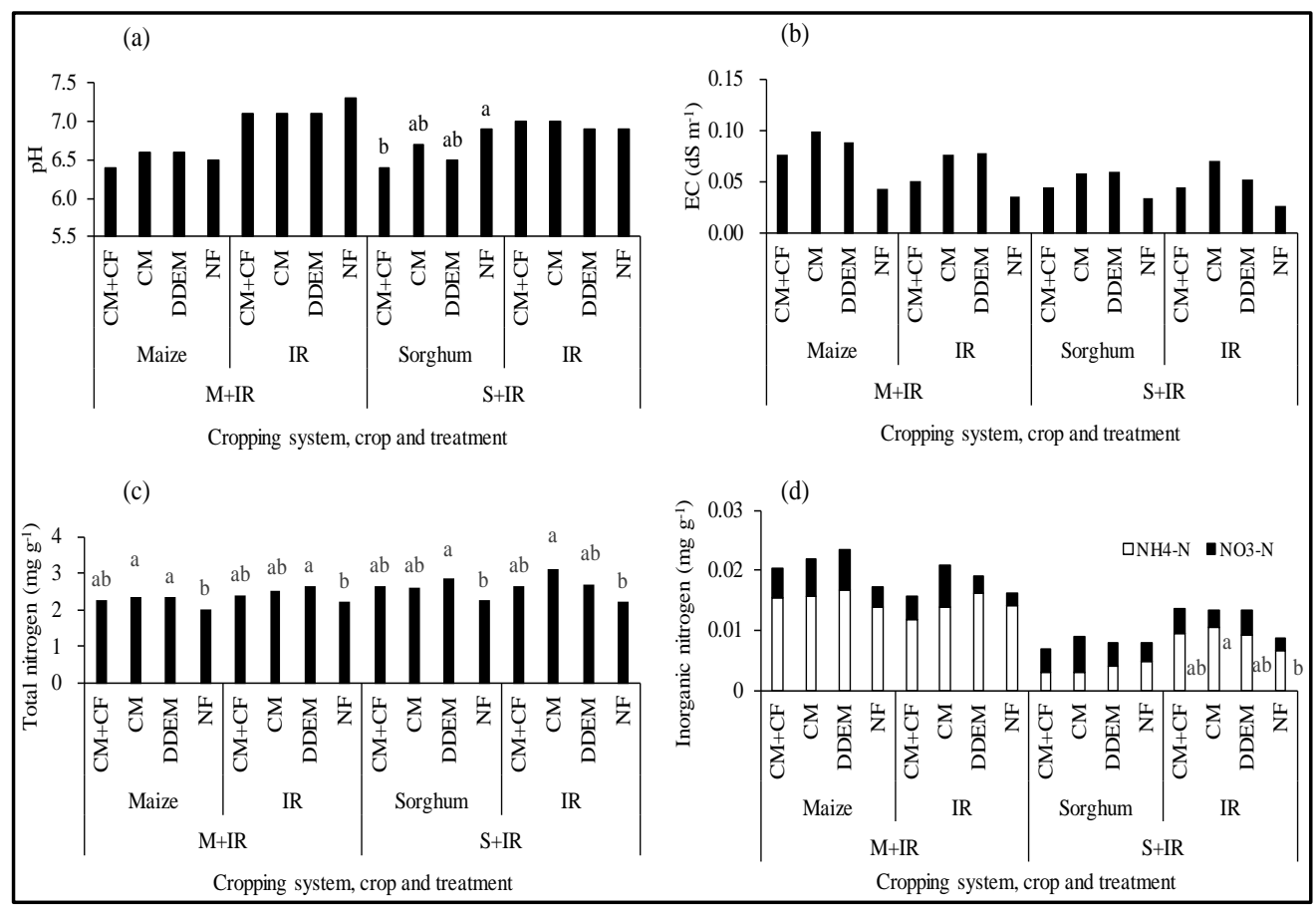

Figure 2. Soil chemical properties in the two summer-winter cropping systems under different fertilizer treatments. Bars with different letters are different within the same crop at the $5 \%$ level (Bonferroni test). For more information on the cropping systems and treatments, refer to the footnote in Table 2. 
ments. For all treatments, soil $\mathrm{pH}$ under both maize and sorghum ranged between 6.4 and 6.9, which is near the optimum $\mathrm{pH}$ for each summer crop. Soil $\mathrm{pH}$ under sorghum was significantly lower for the CM + CF treatment $(\mathrm{P}<0.05)$ than for the NF treatment. However, soil $\mathrm{pH}$ under Italian ryegrass was slightly higher than the optimum $\mathrm{pH}$ range $(6.0$ - 6.5). Soil EC tended to be lower in the NF treatment than in the other treatments in both cropping system. Changes in soil $\mathrm{pH}$ around neutral values and soil EC in a range of $0.05-0.10 \mathrm{dS} \cdot \mathrm{m}^{-1}$ were corresponding with those under liquid DEM application [11]. Total soil $\mathrm{N}$ content was significantly higher for the DDEM treatment than for the NF treatment, except at post-harvest of Italian ryegrass in the sorghum plus Italian ryegrass (S + IR) system. Soil inorganic N content was significantly lower for the NF treatment than the CM treatment at post-harvest of Italian ryegrass in the S + IR system.

\subsection{Nitrogen Recovery Rate in Each Cropping System}

Table 2 shows the apparent $\mathrm{N}$ recovery rate for each crop in the two cropping systems. The $\mathrm{N}$ recovery rates in the maize plus Italian ryegrass (M + IR) system for the CM + CF, DDEM, and CM treatments were 53.2\%, $51.8 \%$, and $43.1 \%$, respectively; $N$ recovery rates in the $\mathrm{S}+\mathrm{IR}$ system tended to be higher than in the $\mathrm{M}+\mathrm{IR}$ system at $61.4 \%, 57.2 \%$ and $52.7 \%$ for the CM + CF, DDEM and CM treatments, respectively. This is probably due to the higher dry matter yields with higher total $N$ content in the S + IR system than in the M + IR system, which were slightly lower than reported for the processed year in Hokkaido, northern Japan [15], and liquid DEM application to M + IR system in southern Kyushu [10]. N recovery rate did not differ significantly among treatments in either cropping system.

\subsection{Change in Available Nitrogen Content of Manure}

Figure 3 shows change in the available N content of DDEM and CM as a function of incubation time. Available $\mathrm{N}$ content increased rapidly in both treatments at the third day of incubation. Between the 3rd and 14th of incubation, available N in DDEM tended to be lower than in CM. After this point, DDEM and CM exhibited similar available $\mathrm{N}$ content around $22 \mathrm{mg} \cdot \mathrm{kg}^{-1}$ until the 28th day of incubation. It is previously reported that at an initial period, inorganic $\mathrm{N}$ immobilization increased up to $200 \mu \mathrm{g} \cdot \mathrm{N} \cdot \mathrm{g}^{-1}$ soil, after amending soil with animal slurries [16]. And the initial inorganic $\mathrm{N}$ decreased after 7 days of incubations and it accounted for $60 \mu \mathrm{g} \cdot \mathrm{N} \cdot \mathrm{g}^{-1}$ soil for soil treated with cattle slurry plus cattle manure plus maize-oat silage [17].

\subsection{Fertilizer Effect of DDEM}

As biogas residues remaining after anaerobic digestion provide a valuable nutrient source, the fertilizer value of the residues has to be accounted for improving nutrient use efficiency at both field and farm levels [18]. DDEM

Table 2. Nitrogen $(\mathrm{N})$ recovery rate in the two summer and winter cropping systems under different fertilizer treatments.

\begin{tabular}{|c|c|c|c|c|}
\hline \multirow{2}{*}{ Cropping system ${ }^{\mathrm{a}}$} & \multirow[t]{2}{*}{ Treatment ${ }^{\mathrm{b}}$} & \multicolumn{3}{|c|}{$\mathrm{N}$ recovery rate (\%) } \\
\hline & & Summer crop & Winter crop & Average in summer and winter crops \\
\hline \multirow{4}{*}{$\mathrm{M}+\mathrm{IR}$} & $\mathrm{CM}+\mathrm{CF}$ & 53.8 & 52.0 & 53.2 \\
\hline & $\mathrm{CM}$ & 57.8 & 39.8 & 51.8 \\
\hline & DDEM & 48.1 & 33.3 & 43.1 \\
\hline & NF & - & - & - \\
\hline \multirow[t]{4}{*}{$\mathrm{S}+\mathrm{IR}$} & $\mathrm{CM}+\mathrm{CF}$ & 65.2 & 54.0 & 61.4 \\
\hline & $\mathrm{CM}$ & 63.1 & 45.4 & 57.2 \\
\hline & DDEM & 58.5 & 41.8 & 52.9 \\
\hline & NF & - & - & - \\
\hline
\end{tabular}

a. Maize (M), Italian ryegrass (IR), Sorghum (S). b. Commercial cattle manure plus chemical fertilizer (CM + CF), Commercial cattle manure (CM), Dehydrated digested effluent of manure (DDEM), No fertilization (NF). 


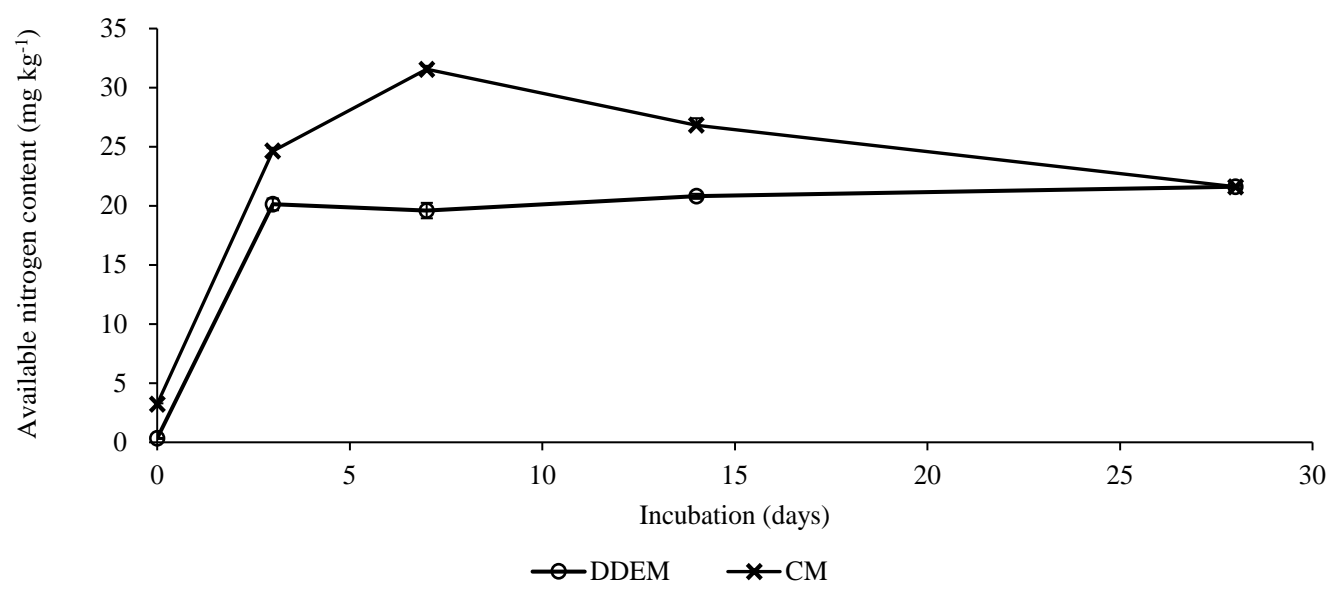

Figure 3. Change in available nitrogen content of dehydrated digested effluent of manure (DDEM) and commercial manure $(\mathrm{CM})$ as a function of incubation time. Mean \pm standard deviation.

treatment did not result in significant differences in dry matter yields, soil chemical properties, or $\mathrm{N}$ recovery rates relative to $\mathrm{CM}+\mathrm{CF}$ and $\mathrm{CM}$ treatments in either cropping system. In the incubation trial, available $\mathrm{N}$ content of DDEM was similar to that of CM at the 28th day. Total N content of DDEM was almost twice that in the commercial cattle manure purchased in Miyazaki Prefecture. In addition, the phosphorus and potassium content of DDEM was higher than the averages for the region [19]. Total soil $\mathrm{N}$ content was significantly higher for the DDEM treatment than for the NF treatment, suggesting that DDEM has the potential to increase total soil $\mathrm{N}$ and, thus, can be used as an alternative organic fertilizer to commercial manure.

\subsection{Adaptability of DDEM to Forage Production System in the Region}

In forage crop cultivation such as maize and sorghum, large quantities of fertilizer must be supplied. Thus, DDEM is suitable for use as a basal fertilizer for these crops. Nitrogen in most organic fertilizers tends to be released slowly, leading to enrichment of the soil $\mathrm{N}$ pool [20]. Large amounts of energy and labor are also required for the transportation and application of DEM [21]. DDEM has a lower specific gravity than CM. As such, it is easier to handle and requires lower transportation costs compared to DEM. Biogas plants produce $\mathrm{CH}_{4}$ as energy and DEM as a fertilizer component. The effective utilization of livestock waste can reduce the environmental load of livestock operations [21].

\section{Conclusion}

Biogas plants to process animal excreta are essential in southern Kyusyu, since they produce renewable energy and effective disposal of livestock waste. The present study indicates that DDEM, a byproduct of biogas plant operations, can replace inorganic fertilizer and commercial cattle manure as a fertilizer in the annual dual-cropping systems that are typical to the region.

\section{Acknowledgements}

Funding for this study was provided by the Ministry of Education, Cultures, Sports, Science and Technology, Japan (organized by Yasuhiro Sugimoto, Prof., PhD).

\section{References}

[1] Harada, H., Yoshimura, Y., Sunaga, Y. and Hatanaka, T. (2000) Variations in Nitrogen Uptake and of Nitrate Nitrogen Concentration among Sorghum Groups. Soil Science and Plant Nutrition, 46, 97-104. http://dx.doi.org/pdf/10.1080/00380768.2000.10408766

[2] Sugimoto, Y. and Hirata, M. (2006) Nitrate Concentration of Groundwater and Its Association with Livestock Farming in Miyakonojo Basin, Southern Kyushu, Japan. Grassland Science, 52, 29-36. http://dx.doi/10.1111/j.1744-697X.2006.00044.x 
[3] Nishinakasu, A., Kirizushi, J., Torihara, M., Sakamoto, H., Tomari, Y., Oohuchiwaki, H. and Miyata, Y. (2007) Research on the Groundwater Pollution by Nitrate Nitrogen. Kagoshima Prefectural Institute for Environmental Research and Public Health Reports, 8, 83-89.

[4] Alberta Agriculture, Food and Rural Development (2005) Manure Compositing Manual. Livestock Engineering Unit \& Environmental Practices Unit Technical Services Division Alberta Agriculture, Food and Rural Development, Alberta, Canada, 1-27.

[5] Saunders, O.E., Fortuna, A., Harrison, J.H., Whitefield, E., Cogger, C.G., Kennedy, A.C. and Bary, A.I. (2012) Comparison of Raw Dairy Manure Slurry and Anaerobically Digested Slurry as N Sources for Grass Forage Production. International Journal of Agronomy, 2012, 1-10. http://dx.doi.org/10.1155/2012/101074

[6] Dordas, C.A., Lithourgidis, A.S., Matsi, T. and Barbayiannis, N. (2008) Application of Liquid Cattle Manure and Inorganic Fertilizers Affect Dry Matter, Nitrogen Accumulation, and Partitioning in Maize. Nutrient Cycling in Agroecosystems, 80, 283-296. http://dx.doi.org/10.1007/s10705-007-9143-1

[7] Iwasaki, M., Yamashiro, T., Beneragama, N., Nishida, T., Kida, K., Ihara, I., Takahashi, J. and Umetsu, K. (2011) The Effect of Temperature on Survival of Pathogenic Bacteria in Biogas Plants. Animal Science Journal, 82, 707-712. http://dx.doi.org/10.1111/j.1740-0929.2011.00887.x

[8] Matsunaka, T., Kumai, M. and Sentoku, A. (2003) Evaluation of Anaerobically Digested Cattle Slurry as a Nitrogen Source for Orchardgrass. Japanese Journal of Soil Science and Plant Nutrition, 74, 31-38.

[9] Nakamura, M., Fujikawa, T., Yuyama, Y., Yamaoka, M. and Oritake, F. (2012) Influence of Application Method on Emissions of Ammonia and Nitrous Oxide Following Application of Methane-Fermentation-Digested Slurry. Japanese Journal of Soil Science and Plant Nutrition, 83, 139-146.

[10] Idota, S., Asano, Y., Sugimoto, Y. and Ishii, Y. (2013) Effect of Digested Effluent of Manure on Yield, Forage Quality and Nitrogen Recovery Rate of Maize-Italian Ryegrass Cropping System in Southern Kyushu. Japanese Journal of Grassland Science, 58, 230-240.

[11] Hasyim, H., Ishii, Y., Wadi, A. and Idota, S. (2014) Effect of Digested Effluent of Manure on Soil Nutrient Content and Production of Dwarf Napiergarss in Southern Kyushu, Japan. Journal of Agronomy, 13, 1-11. http://dx.doi.org/10.3923/ja.2014.1.11

[12] Editorial Committee for Analytical Method of Soil Environments (1997) Analytical Method of Soil Environments. Hakuyusya, Tokyo, 1-427.

[13] Matsunaka, T., Naruse, M. and Kumai, M. (2002) Change in Nutrients Content and Some Other Properties of Dairy Cattle Slurry Following Anaerobic Digestion. Japanese Journal of Soil Science and Plant Nutrition, 73, 297-300.

[14] Herrmann, H., Sieling, K., Wienforth, B., Taube, F. and Kage, H. (2013) Short-Term Effects of Biogas Residue Application on Yield Performance and N Balance Parameters of Maize in Different Cropping Systems. Journal of Agricultural Science, 151, 449-462. http://dx.doi.org/10.1017/S0021859612000548

[15] Okamoto, M., Shimizu, K. and Yoshihira, T. (2002) The Application Levels of Anaerobically Digested Slurry and Nitrogen Balance and Digestibility of Corn Silage. Japanese Journal of Livestock Management, 38, 64-65.

[16] Kirchmann, H. and Lundvall, A. (1993) Relationship between N Immobilization and Volatile Fatty Acids in Soil after Application of Pig and Cattle Slurry. Biology and Fertility of Soils, 15, 161-164. http://dx.doi.org/10.1007/BF00361605

[17] Alburquerque, J.A., Fuente, C. and Bernal, M.P. (2012) Chemical Properties of Anaerobic Digestates Affecting C and N Dynamics Inamended Soils. Agriculture, Ecosystems and Environment, 160, 15-22. http://dx.doi.org/10.1016/j.agee.2011.03.007

[18] Sieling, K., Herrmann, A., Wienforth, B., Taube, F., Ohl, S., Hartung, E. and Kage, H. (2013) Biogas Cropping Systems: Short Term Response of Yield Performance and N Use Efficiency to Biogas Residue Application. European Journal of Agronomy, 47, 44-54. http://dx.doi.org/10.1016/j.eja.2013.01.002

[19] Miyazaki Animal Husbandry Society (2008) Miyazaki Prefecture Manure Information, Guidelines for Manure Application, Miyazaki Prefecture, Miyazaki, 1-4.

[20] Gutser, R., Ebertseder, T.H., Weber, A., Schraml, M. and Schmidhalter, U. (2005) Short-Term and Residual Availability of Nitrogen after Long-Term Application of Organic Fertilizers on Arable Land. Journal of Plant Nutrition and Soil Science, 168, 439-446. http://dx.doi.org/10.1002/jpln.200520510

[21] Nakamura, M. (2011) Environmental Impacts of Methane Fermentation Digested Slurry as a Liquid Fertilizer. Bulletin of National Institute for Rural Engineering, 50, 1-57. 
Scientific Research Publishing (SCIRP) is one of the largest Open Access journal publishers. It is currently publishing more than 200 open access, online, peer-reviewed journals covering a wide range of academic disciplines. SCIRP serves the worldwide academic communities and contributes to the progress and application of science with its publication.

Other selected journals from SCIRP are listed as below. Submit your manuscript to us via either submit@scirp.org or Online Submission Portal.
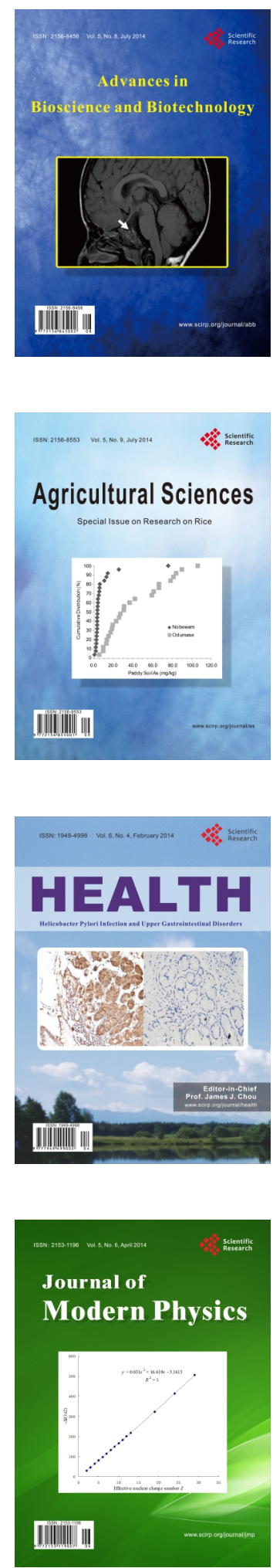
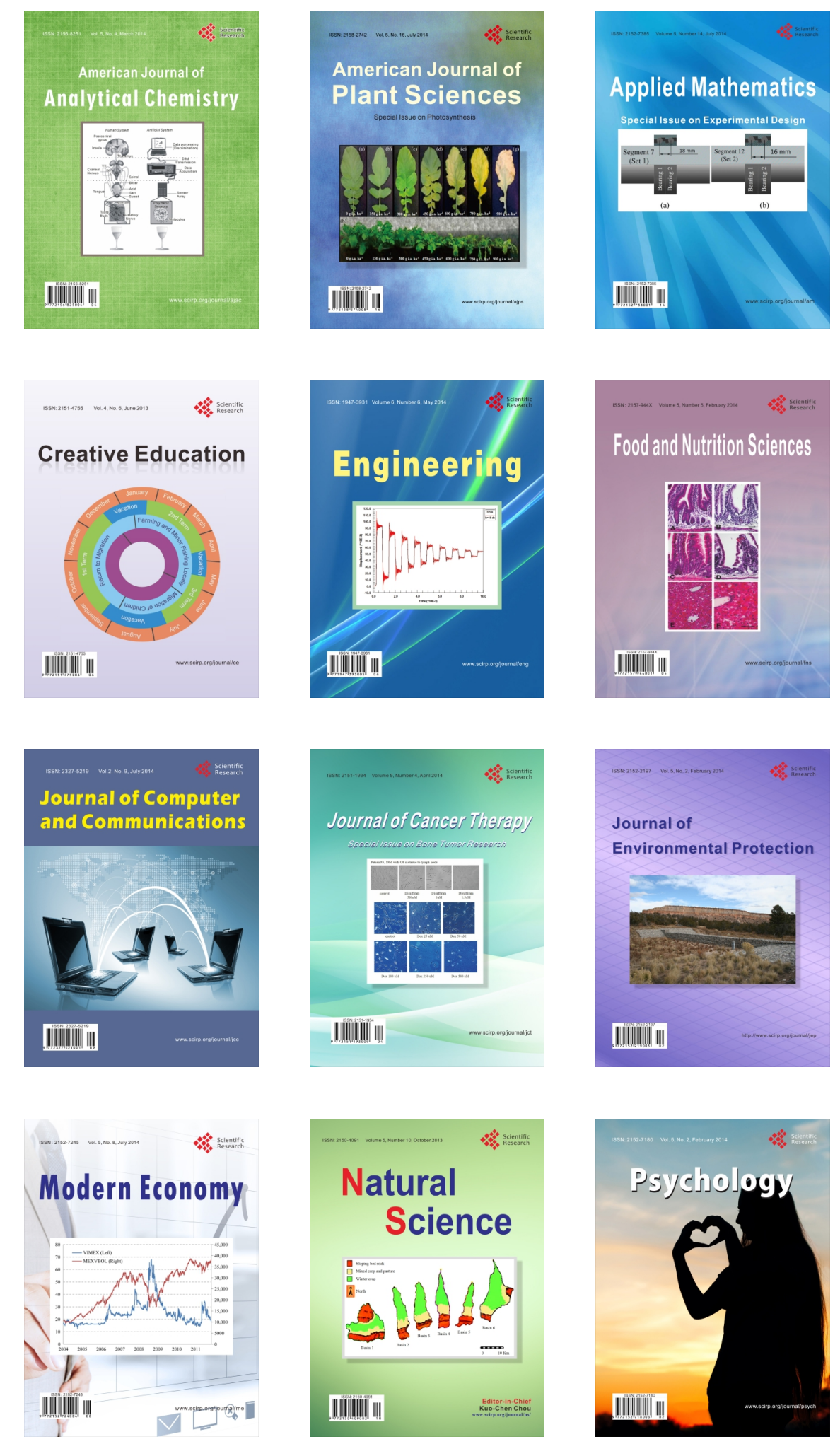